\title{
Macromodel of interfacial transition layer in ceramic matrix composites
}

\author{
Andrey Stolboushkin ${ }^{1,}$, Vadim Syromyasov ${ }^{1}$, Vladimir Vereschagin ${ }^{2}$, and Oksana Fomina ${ }^{1}$ \\ ${ }^{1}$ Siberian State Industrial University, 654007 Novokuznetsk, Russia \\ ${ }^{2}$ National Research Tomsk Polytechnic University, 634050 Tomsk, Russia
}

\begin{abstract}
The purpose of the study is to create a macromodel of interfacial transition layer in ceramic matrix composites. Chemical and mineralogical compositions were investigated by means of X-ray fluorescence analysis and X-ray diffractometry, ceramic and technological properties of raw materials were defined using standard test methods for argillaceous raw materials. Phase composition and structure of ceramic specimens were studied using a complex of modern physico-chemical analysis methods. The layer-by-layer model of shell-core transition in ceramic matrix material was suggested. Boundary conditions for obtaining specimens were defined in terms of number of layers, thickness of such layers and pitch of core-to-shell material ratio. Forced air supply was organized while burning for directed heat and mass transfer inside the specimens. Mineral composition of layers was defined for ceramic specimens with the core of iron ore waste and the shell of clay. The study enabled to determine dependences between qualitative and semiquantitative variation of new mineral formations content in transitional layers of a composite, which is the evidence of interaction between the core and the shell products while burning a ceramic matrix material.
\end{abstract}

\section{Introduction}

Scarcity of high quality clay resources generates the need for search of alternative raw materials for ceramic building products. Off-spec silica raw materials and industrial mineral waste can be used as additional raw material source [1-5]. At the same time, slow development of technogenic deposits for ceramic products manufacturing is connected with insufficient previous studies on physico-chemical processes that occur while burning such raw materials [6-10].

New approaches to directed structure formation at the stages of raw materials and molding composition preparation and unburnt brick compaction are required to obtain ceramic bricks with specified physico-mechanical properties from off-spec natural raw materials and industrial mineral waste [11-13]. Technological principles for obtaining ceramic matrix composites were developed by the authors of the study [14]. Modeling of layer-by-layer transition between core and shell in ceramic matrix composites enables to control structure formation processes and, in the end, to obtain tailored ceramic products.

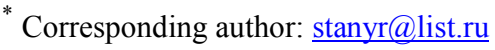


Based on the previous research, the authors developed a framework for formation of matrix transition layers on a macrolevel and prepared model specimens. Critical conditions for obtaining macromodels were defined and factors to increase their performance were considered $[15,16]$.

Specialists emphasize the necessity to develop and use new research methods, along with standard ones, for studying ceramics made from technogenic raw materials with new structural and mechanical characteristics [17-21]. The novelty of this research compared to other studies is selectivity while studying interphase boundaries in ceramic matrix composites using a transition layer macromodel.

The purpose of this research is to study phase composition and structure of interfacial transition layers between core and shell of ceramic matrix composite made of iron ore waste and argillaceous raw materials.

\section{Framework for macromodel development}

The framework to obtain ceramic specimen models consisted in formation of successive layers with various percentage of raw material components (Fig. 1).
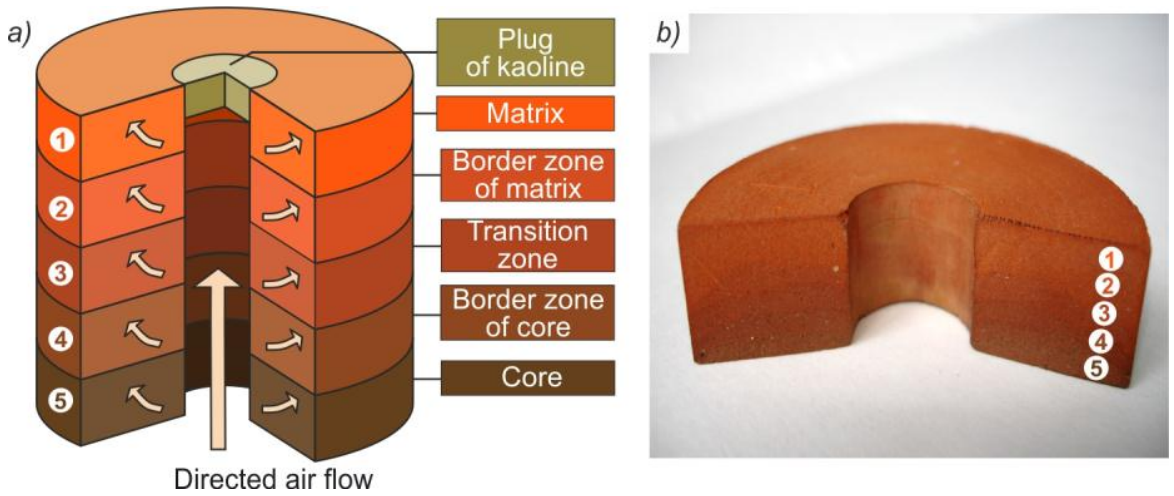

Fig. 1. Scheme of transition layer formation between shell and core in a matrix composite (a) and its specimen model after burning at $1000{ }^{\circ} \mathrm{C}$ (b): 1 - matrix (shell); 2 - border zone of matrix (shell); 3 transition zone; 4 - border zone of core; 5 - core.

According to the developed method for obtaining ceramic matrix composite products, argillaceous batch components roll up onto the surface of waste granules in the process of their formation. At the same time, both raw materials partially mix in the border zone. Distribution of both components at the waste $\leftrightarrow$ clay border in the total mass changes integrally from 100 to $0 \mathrm{wt} . \%$, and conversely. By differentiating this smooth transition into several zones with a certain components ratio, one can approximately model a phase boundary (dispersed phase $\leftrightarrow$ dispersion medium) in a ceramic matrix composite. A specimen model is obtained by forming successively several different layers (Fig. 1, b).

Optimum conditions for obtaining a macromodel were defined using design and experimental methods. Previously, the number of transition layers varied from 1 to 5 . The experiment showed that one or two transition layers provide a rough approximation of the model in relation to the real matrix structure condition. While forming specimens with five transition layers a problem of obtaining uniform layer thickness appears. That is why the optimum number of transition layers in a model is 3 , while the total number of layers is 5 . Investigation was performed to decrease the layer thickness to the minimum possible one enabling to perform material sampling for further X-ray diffraction analysis [15]. Such investigation allowed approximating the model to the real conditions of boundary transition 
between core and matrix. To intensify the processes of heat and mass transfer and interaction between layers, it was suggested to organize forced air change while burning. Special molds were designed for this purpose, using which cylinder specimens with end-toend holes can be produced [16].

\section{Materials and Methods}

\subsection{Raw materials for macromodel preparation}

The suggested model (Fig. 1) was tested using the following raw materials. Iron ore waste from the Abagursky ore-dressing plant (Novokuznetsk city, Russia) was used as core material, and slightly plastic Novokuznetsk loam was used as matrix material.

Mineral part of iron ore waste consists of feldspars, quartz, mica, pyroxenes, amphiboles, ferruginous chlorites, and contains small amount of mixed-layer argillaceous formations. The material is fine-grained (with the average grain size of 15-18 microns), slightly plastic (with plasticity index less than 4), non-sintering and has low drying sensitivity.

Novokuznetsk loam contains less than $1 \%$ of coarse-grained particles $(>0.5 \mathrm{~mm})$. The amount of clay fraction particles $(<0,001 \mathrm{~mm})$ is less than $20-30 \%$. Loam has high drying sensitivity and belongs to hydromicaceous-montmorillonitic type based on its argillaceous minerals characteristics. Non-plastic part of loam is represented by quartz, carbonate, feldspars, chlorite and amphiboles.

Chemical composition of raw materials is given in Table 1.

Table 1. Chemical composition of raw materials.

\begin{tabular}{|l|c|c|c|c|c|c|c|c|c|c|c|c|}
\hline & \multicolumn{7}{|c|}{ Mass fraction of components, \% (on a dry basis) } \\
\cline { 2 - 12 } Raw material & $\mathrm{SiO}_{2}$ & $\mathrm{Al}_{2} \mathrm{O}_{3}$ & $\mathrm{FeO}$ & $\mathrm{Fe}_{2} \mathrm{O}_{3}$ & $\mathrm{CaO}$ & $\mathrm{MgO}$ & $\mathrm{TiO}_{2}$ & $\mathrm{MnO}$ & $\mathrm{R}_{2} \mathrm{O}$ & $\mathrm{P}_{2} \mathrm{O}_{5}$ & $\mathrm{SO}_{3}$ & $\begin{array}{c}\text { Loss } \\
\text { on } \\
\text { ignition }\end{array}$ \\
\hline Iron ore waste & 32.74 & 8.99 & 5.70 & 13.59 & 14.37 & 10.88 & - & 0.59 & 1.15 & 0.24 & 1.45 & 10.3 \\
\hline $\begin{array}{l}\text { Novokuznetsk } \\
\text { loam }\end{array}$ & 62.03 & 14.71 & 5.07 & 4.56 & 2.49 & 0.93 & 0.21 & 3.94 & - & 0.47 & 5.59 \\
\hline
\end{tabular}

\subsection{Macromodel design method}

According to the section 2, ceramic hollow cylinder specimens with the diameter of $60 \mathrm{~mm}$ and the height of $20-25 \mathrm{~mm}$ were prepared using semidry pressing method (Fig. 1, b). Amount and composition of raw materials components of the layers are given in Table 2. Moisture of ceramic batch components was 9-9.5 wt.\%, pressure value was $15 \mathrm{MPa}$. The specimens were burnt at $1000{ }^{\circ} \mathrm{C}$ and cured for 1 hour at maximum temperature.

Table 2. Composition of raw materials for model specimens.

\begin{tabular}{|l|c|c|c|c|c|}
\hline \multirow{2}{*}{ Raw material } & \multicolumn{5}{|c|}{ Content of batch components depending on the layer number, wt. \% } \\
\cline { 2 - 6 } & 1st layer & 2nd layer & 3rd layer & 4th layer & 5th layer \\
\hline Iron ore waste & - & 25 & 50 & 75 & 100 \\
\hline $\begin{array}{l}\text { Novokuznetsk } \\
\text { loam }\end{array}$ & 100 & 75 & 50 & 25 & - \\
\hline
\end{tabular}

While preparing multilayer specimens, accurate batching of mold powder was ensured 
for each layer on the volume basis. The layer thickness was 4-5 $\mathrm{mm}$. Molding material moisture control was performed for each layer. Finely fragmented components were dried to constant mass. Accurate amount of water was calculated for prepared batch compositions. Mold powders were simultaneously kept in a desiccator for 6 hours for moisture leveling.

In order to organize directed heat and mass transfer inside a specimen and trigger layers interaction, one side of the end-to-end cylindrical hole was tightly plugged with a combination of kaolin wool and clay. On the opposite side of the model specimen, directed air flow was supplied into the hole (Fig.1, a).

\subsection{Macromodel research methods}

Radiographical studies of the layers which modeled the layer-by-layer transition from matrix to core were performed using XRD-6000 X-Ray diffractometer (Shimadzu, Japan). Powders obtained from each level were studied in the range of $2 \theta$ from $4^{\circ}$ to $80^{\circ}$ at room temperature using FeK $\alpha$ radiation (Wavelength $1.936040 \AA$ ). Diffractometer settings were as follows: $40 \mathrm{kV}, 30 \mathrm{~mA}$, continuous scan mode, $2 \theta$ step width $0.02^{\circ}$ and speed $2 \mathrm{deg} / \mathrm{min}$. Phase composition analysis was performed with the help of Match!3 (Crystal impact, Germany) software and the PDF-2 data of The International Centre for Diffraction Data.

Microstructure and chemical composition of the matrix and core layers of the specimen were investigated using JSM-6460LV (JOEL, Japan) scanning electron microscope and a device for energy dispersive X-ray analysis (INCA Energy-350, Oxford Instruments).

\section{Experiment}

X-ray diffraction patterns of the model specimen layers showed presence of the following solid mineral phases: quartz $(4.255 ; 3.343 ; 2.128 \AA$, etc.), hematite $(2.69 ; 2.25 ; 1.843$; $1.697 \AA)$, feldspars $(4.03 ; 3.78 ; 3.484 \AA$, etc.), spinel $(4.67 ; 2.85 ; 2.43 \AA)$, augite $(3.204$; $2.989 ; 2.917 ; 2.550 \AA)$, diopside $(2.512 ; 2.985 ; 2.943 \AA)$ and olivine $(1.748 ; 2.510$; $2.457 \AA$ ). Their intensity and semiquantitative content are presented in Figure 2.

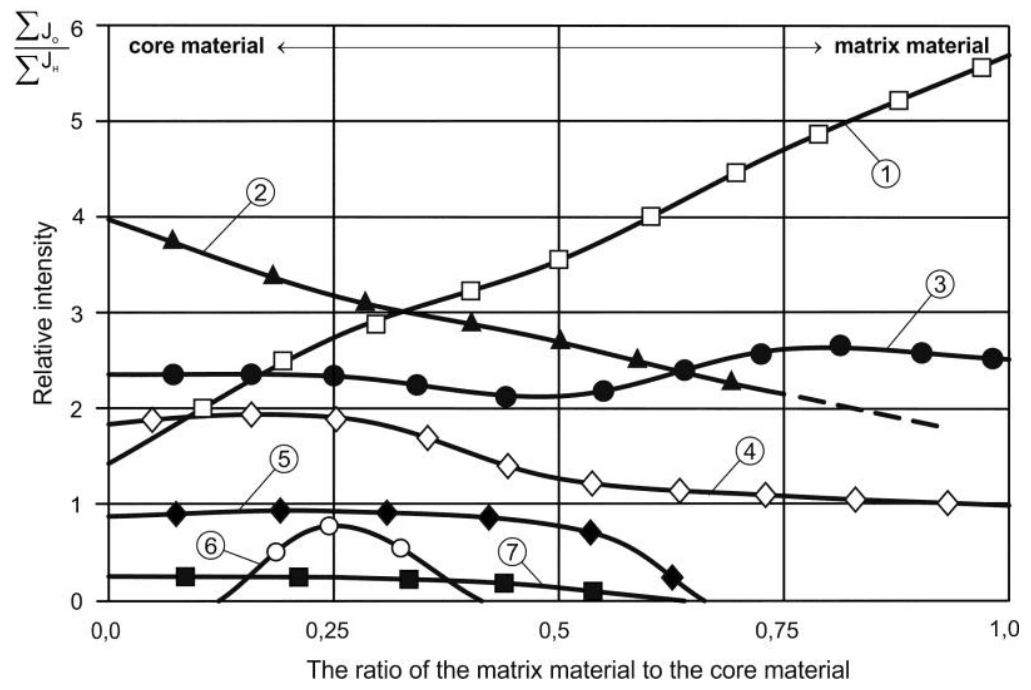

Fig. 2. Variation of total intensity of the minerals while core to matrix transition in a ceramic matrix composite: 1 - quartz; 2 - hematite; 3 - feldspar; 4 - augite; 5 - spinel; 6 -diopside; 7 - olivine. 
Analysis of the curvatures of intensity variations showed that quartz crystal amplitude increases with the increase of content of matrix material in relation to core material from 0 to 1 , which is explained by higher content of quartz crystal in loam. Layer-by-layer decrease of hematite intensity towards the matrix is caused by lower content of ferrous oxide in argillaceous component compared to that of iron ore waste. With the increase of loam amount in layers content after burn, spinel and olivine become less intense and are almost absent in the layer formed of loam only. The intensity of feldspar has almost no change in transition from core to matrix of ceramic matrix specimen, irrespective of layers initial content. The line of augite intensity indicates decrease in reaction of pyroxene mineral formations while transition to matrix of the composite material.

Therefore, the main crystal phases of transition layers and the core are quartz, hematite, feldspar and augite. The same minerals except hematite are present in the matrix. The amount of quartz rises from core to matrix due to quartz component in loam. Spinel and olivine are contained in the core in small amounts, but they disappear in layers that are close to the matrix.

Studies of microstructure and chemical composition of core and matrix layers of a model specimen are presented in Figure 3 and in Table 3.

By using average values, high content of $\mathrm{Fe}, \mathrm{Ca}$ and $\mathrm{Mg}$ was found in the model core layer compared to the matrix layer. Such phenomenon is caused by their predominance in iron ore waste and confirms formation of augite ( $\mathrm{Ca}, \mathrm{Fe}, \mathrm{Mg})_{2} \mathrm{Si}_{2} \mathrm{O}_{3}$ and diopside $\mathrm{CaMgSi}_{2} \mathrm{O}_{6}$ while burning. Higher content of $\mathrm{Na}$ and $\mathrm{K}$ was found in the matrix layer compared to the core layer.
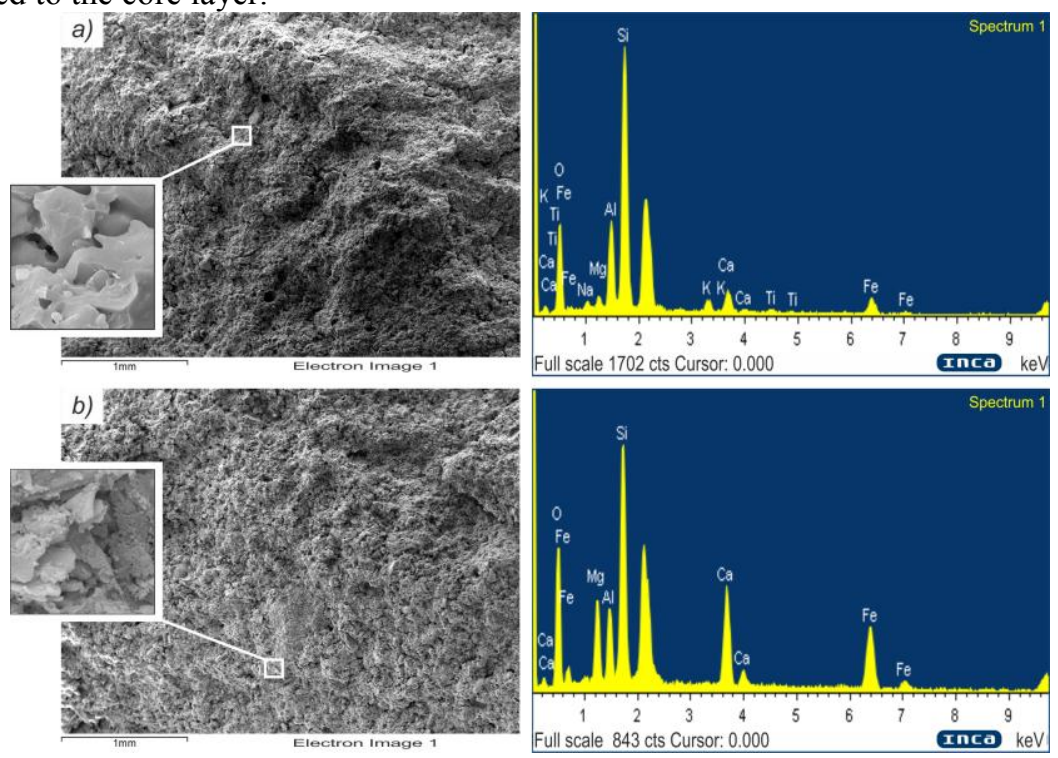

Fig. 3. X-ray microanalysis of matrix (a) and core (b) layers in model specimen burnt at $1000{ }^{\circ} \mathrm{C}$.

Table 3. Element composition of core layer and matrix of model specimen.

\begin{tabular}{|c|c|c|c|c|c|c|c|c|c|c|}
\hline \multirow{3}{*}{ Zone } & \multirow{2}{*}{$\begin{array}{c}\text { Element } \\
\text { composition of } \\
\text { crystal phase }\end{array}$} & \multicolumn{10}{|c|}{ Chemical element } \\
\cline { 3 - 12 } & $\mathrm{O}$ & $\mathrm{Na}$ & $\mathrm{Mg}$ & $\mathrm{Al}$ & $\mathrm{Si}$ & $\mathrm{K}$ & $\mathrm{Ca}$ & $\mathrm{Ti}$ & $\mathrm{Fe}$ \\
\hline \multirow{2}{*}{ Matrix } & weight, \% & 39.56 & 1.13 & 1.57 & 9.65 & 33.23 & 2.30 & 4.12 & 0.62 & 7.83 \\
\cline { 2 - 12 } & atomic, \% & 55.67 & 1.11 & 1.45 & 8.05 & 26.64 & 1.32 & 2.31 & 0.29 & 3.16 \\
\hline \multirow{2}{*}{ Core } & weight, \% & 34.62 & 0.74 & 6.81 & 6.34 & 19.97 & 0.46 & 10.58 & 0.00 & 20.49 \\
\cline { 2 - 11 } & atomic, \% & 53.24 & 0.79 & 6.89 & 5.78 & 17.49 & 0.29 & 6.49 & 0.00 & 9.03 \\
\hline
\end{tabular}


Using the investigation data on microstructure and chemical composition of matrix and core layers of a model specimen, we can conclude that alkali elements interact with $\mathrm{Si}, \mathrm{Al}$, $\mathrm{Mg}, \mathrm{Fe}$ and ensure increased content of liquid phase in the boundary layer (Fig. 3).

\section{Results}

The determined dependences of new mineral formations variation in transition zone between core and matrix are the evidence of interaction between the core and the matrix products while burning a ceramic matrix material.

Presence of identical crystal phases in the core, transition layers and the matrix of sintered loam excludes occurrence of thermal stresses on the core $\leftrightarrow$ matrix boundary.

The obtained experimental data of X-ray diffraction analysis coincide with the forecast of suggested solid phase reactions behavior.

\section{Conclusion}

The conducted research proved the relevance of the developed scientific hypothesis of modeling core to matrix transition in ceramic matrix composite in the form of discrete layers with different content of raw components. According to the authors, evaluation of layer-by-layer change of phase composition of mineral formations in model specimens' layers enables to forecast the minimum required amount of argillaceous batch components to provide the required operational properties of the product. Such evaluations shall be done along with studying physico-mechanical properties of materials, as well as chemical, structure and phase transition while burning. Further investigation in this field will include development of method of batch component design for obtaining ceramic matrix composites depending on the type, chemical and mineral compositions and ceramic and technological properties of technogenic and natural raw materials. This way, relevance and prospects for this research direction is provided.

The research was performed in the framework of State Assignment of the Ministry of Education and Science of the Russian Federation, project code No. 7.7285.2017/8.9 "Basic research on ceramic matrix composite building materials based on technogenic and natural raw materials".

\section{References}

1. B.K. Kara-Sal, D.H. Sat, Sh.V. Seren, D.S. Mongush, Stroitel'nye Materialy [Construction Materials], 4, 33-36 (2016) (in Russian)

2. E. Wolff, W.K. Schwabe, S.V. Conceição, J.A. Santanna-Greco, M. Greco, R.R.Machado, Clean Technologies and Environmental Policy, 19(2), 379-389 (2017)

3. T.V. Vakalova, V.M. Pogrebenkov, I.B. Revva, Siberian Journal of Science, 1(2), 339-347 (2012) (in Russian)

4. A.M. Salakhov, K.A. Ariskina, R.A. Ariskina, Georesources, 18(3), 236-239 (2016) (in Russian)

5. L. Zhang, Construction and Building Materials, 47, 643-655 (2013)

6. V.A. Guryeva, V.V. Prokofyeva, Stroitel'nye Materialy [Construction Materials], 4, 55-57 (2014) (in Russian)

7. L.F. Zhang, S.J. Xiao, S. Chen, X.G. Chen, C.Z. Dong, Y.B. Zhang, Advanced Materials Research, 652-654, 294-297 (2013)

8. A.F. Khuzin, A.A. Lamberov, S.R. Egorova, O.V. Sroyanov, M.G. Gabidullin, Herald of Kazan Technological University, 18(16), 89-91 (2015) (in Russian) 
9. R.M. Nafikov, G.R. Faseeva, A.M. Salakhov, A.I. Hatsrinov, Herald of Kazan Technological University, 8, 224-229 (2010) (in Russian)

10. T. L. Lazareva, E.S. Kulikova, Technical Sciences - theory and practice, 55, 135-140 (2016) (in Russian)

11. J. Martın-Marquez, J.M. Rincon, M. Romero, Ceram. Int., 34, 1867-1873 (2008)

12. V.F. Pavlov, Stroitel'nye Materialy [Construction Materials], 8, 28-30 (2003) (in Russian)

13. V.P. Tarasevich, Stroitel'nye Materialy [Construction Materials], 5, 5-8 (1992) (in Russian)

14. A.Yu. Stolboushkin, G.I. Berdov, V.I. Vereshchagin, O.A. Fomina, Stroitel'nye Materialy [Construction Materials], 8, 19-23 (2016) (in Russian)

15. A.Yu. Stolboushkin, V.A. Syromyasov, A.I. Ivanov, N.V. Petrova, Dolgovechnost' stroitel'nyh materialov, izdelij i konstrukcij [Durability of building materials, products and structures], Proceedings of the All-Russian Scientific and Practical Conference, 161-166 (Saransk, 2016) (in Russian)

16. A.Yu. Stolboushkin, V.A. Syromyasov, A.I. Shcherbina, N.V. Petrova, Proceedings of the II Bryansk International Innovative Forum - Construction-2016, 1, 153-158 (Bryansk State University of Engineering and Technology, Bryansk, Russia, December 1, 2016) (in Russian)

17. M.D. Herd, Materials and Manufacturing Processes, 8(2), 259-264 (1993)

18. A.Walter, R. Herber, C. Hess, T. Ressler, Chemistry Central Journal, 4(December), 43 (2010)

19. J. Malaiskiene, R. Maciulaitis, Procedia Engineering, 57, 739-745 (2013)

20. V.D. Kotlyar, Yu.V. Terekhina, A.V. Kotlyar, Stroitel'nye Materialy [Construction Materials], 4, 24-27 (2014) (in Russian)

21. N.D. Yatsenko, A.P. Zubekhin, Stroitel'nye Materialy [Construction Materials], 4, 28 31 (2014) (in Russian)

22. A.Y. Stolboushkin, O.A. Fomina, News of Higher Educational Institutions. Construction, 7, 23-35 (2016) (in Russian) 